\title{
Bioactivities of Azadirachta indica, Murraya koenigii, liquorice and Nicotiana tobacum against two strains of Callosobruchus chinensis $\mathbf{L}$.
}

\author{
Shireen Raza Haidri ${ }^{1, *}$, Farooq Ahmad ${ }^{1}$, Mansoor-ul-Hasan ${ }^{1}$ and Nazir Javed ${ }^{2}$ \\ ${ }^{1}$ Department of Entomology, University of Agriculture, Faisalabad, Pakistan; ${ }^{2}$ Department of Plant Pathology, University of \\ Agriculture, Faisalabad, Pakistan \\ *Corresponding author’s e-mail: shireenraza2309@gmail.com
}

\begin{abstract}
The current research work was conducted for the evaluation of repellent and growth inhibitory potential of Azadirachta indica, Murraya koenigii, Nicotiana tobacum and Liquorice against Callosobruchus chinensis (L.). Each plant extract was tested with four concentrations viz; 5, 10, $15 \& 20 \%$ for bioassay experiments. Repellent potentials of acetone extract of the plants were evaluated by using the area preference method against the pulse beetle. The four dilutions of the extracted plant materials (extract) were used at one half of the filter papers (of each) while remaining halves were solely treated with acetone (used as control experimental unit) for the comparison purposes. Data regarding repellence were taken after 12, 24 and 48 hours of the post treatment. In repellency bioassay, the highest (93.32\%) repellence of Callosobruchus chinensis was observed for which against $20 \%$ concentration of $A$. indica extract, whereas lowest repellence $(78.87 \%)$ was recorded in case of Liquorice. Repellency values of $90.07 \%$ and $84.76 \%$ were recorded in extracts of $M$. koenigii and $N$. tobacum in Faisalabad strain. In case of Lahore strain highest repellence of $C$. chinensis was observed for which $95.16 \%$ at $20 \%$ concentration of $A$. indica extract was whereas relatively lowest value (82.04\%) was recorded in case of Liquorice. Repellency values of $87.27 \%$ and $91.06 \%$ were recorded in extracts of $M$. koenigii and $N$. tobacum. The results regarding growth inhibitory effect revealed that highest mean progeny inhibition (78.12\%) was noted at $20 \%$ dose rate of $A$. indica extracted plant material after longest exposure time (60 days). Comparatively lowest inhibition (28.21\%) was noted after 30 days exposure period at 5\% dilution of Liquorice extract in Faisalabad strain. Mean inhibition of progeny was found directly dependent on both time as well as concentration, applied. Results revealed that highest mean progeny inhibition (85.03\%) was recorded at $20 \%$ concentration of $A$. indica extract after longest exposure time (60 days). Comparatively, lowest inhibition $(35.18 \%)$ was recorded at 5\% after 30 days of application of Nicotiana tobacum extract in Lahore strain. Hence, use of plant-based materials can be helpful for the ecofriendly management of the stored grains insect pests as a part of IPM program.
\end{abstract}

Keywords: Callosobruchus chinensis, chickpea, green pesticides, deterrence, growth inhibition, time of exposure.

\section{INTRODUCTION}

The Pulse beetles (Callosobruchus chinensis) one of the most damaging insect pest, is also known as Dhora beetle. It is responsible for infesting stored pulses (Righi-Assia et al., 2010). As a cosmopolitan insect it is found all over the world (Verma and Anandi, 2010). In storage and field conditions $C$. chinensis cause both qualitative and quantitative losses to stored chickpea (Das et al., 2005 and Naveena et al., 2009). It causes more than $10 \%$ damages to chickpea during storage in Punjab (Aslam et al., 2004) It is reported that up to 60 percent losses occurs in pulses 50-67 percent losses in seed weight by the attack of the bruchids (Gujar and Yadav, 1978). All over the world the synthetic insecticides (Organophosphates and pyrethroids) and fumigants (methyl bromide and phosphine) have been used for the control of insect pests of stored commodities. In storage conditions for the protection of the food commodities these synthetic insecticides are used as protectants (EPA, 2001). But it is reported that these insecticides contribute as a biggest source of pollution in the environment. Similarly, removal of the beneficial organisms from the environment and residual effects in harvested crops may found by the use of the synthetic insecticides (Anand $e t$ al., 2008; Chinnaiah et al., 1998). Resistance has been observed in numbers of stored grain insect pests by the application of the synthetic insecticides (Subramanyam and Hagstrum, 1995; Srivastava and Singh, 2002).

Haidri, S.R., F. Ahmad, M.U. Hasan and N. Javed. 2021. Bioactivities of Azadirachta indica, Murraya koenigii, liquorice and Nicotiana tobacum against two strains of Callosobruchus chinensis L. Pak. J. Agri. Sci.58:1155-1159.

[Received 17 Sep 2020; Accepted 21 Feb. 2021; Published (online) 21 Sep 2021] 
Plant extracts are organic substances derived from the different plant parts. In soil they are easily degradable and there is no deposition of the plant extracts in the tissues of the living organisms. Tropical farmers are well known by the application of extracted plant materials and applicate their crops against the insect pests (Araya and Emana, 2009). Botanicals are environmentally pollution free and had no harmful effects for human beings and other living things in comparison with the other pesticides (Isman, 2002, Debashri and Tamal, 2012). Degradation of plant based insecticides takes place within a few hours or days. Extracted plant materials are pest specific and are harmless for non-target organisms (Guleria and Tiku, 2009).

Among the natural plants, powders of the plants were used as protectants for the safety of the crops (Isman, 2002). Plant extracts caused repellency when the insects contact with these botanicals (Boeke et al., 2004). A number of plants recognized for the insecticidal properties (Kamakshi et al., 2000, Maheshwari and Dwivedi, 1996). Sharma (2013) conveyed the effectiveness of many extracted plant materials against $C$. chinensis. Most of the extracted plant materials had a number of characteristics like fast knock down, antifeedant, repellency, biodegradability and cause reduction in resistance of insects also (Reddy et al., 2012).

Keeping in view, following were the objectives of the proposed study;

- To check the repellent effects of dissimilar concentrations of A. indica, M. koenigii, N. tobacum and Liquorice against two geographical strains of Callosobruchus chinensis.

- To evaluate the progeny inhibition potential of the dissimilar concentrations of the plant extracts against the two strains of Callosobruchus chinensis.

\section{MATERIALS AND METHODS}

Experiments were performed in Stored Grain Research, Training and Storage Management Cell, Department of Agricultural Entomology, University of Agriculture, Faisalabad in year 2018-19. Materials consists of Azadirachta indica, Murraya koenigii, Liquorice and Nicotiana tobacum and insects (Callosobruchus chinensis).

Rearing of insects: From the grain market, mix aged adults of $C$. chinensis were collected from Lahore (LHR), and Faisalabad (FSD) and were reared in the laboratory at optimum conditions to get the homogenous population of $C$. chinensis up to six generations. To get the homogenous population of $C$. chinensis in the laboratory at optimum conditions, $C$. chinensis population was reared in sterilized glass jars. For the coupling and egg lying of test insect 100 adults of $C$. chinensis were released into the jars after adding $500 \mathrm{~g}$ grains of chickpea. The jars were tightened with rubber bands after covering with muslin cloth to avoid the escape of test insects. Optimum conditions $25 \pm 2{ }^{\circ} \mathrm{C}$ and $60 \%$ R.H. were maintained for the rearing of the test insects. Adults were sieved after five days and the jars filled with grains along with eggs were kept under optimum conditions to get homogenous population.

Preparation of plant extracts: Leaves of Nicotiana tobacum (tobacco), stem of Liquorice (mulathi), Murraya koenigii (curry patta) and Azadirachta indica (neem) were collected. After drying of plant materials to get the homogenous powder, the plant materials were grinded in electric grinder. About $50 \mathrm{gm}$ of powder were mixed with $100 \mathrm{ml}$ of acetone and then rotary shaker was used to shake the mixture for 24 hours. After that the extracts were filtered. For the removal of excess acetone in primary extract the rotary evaporator was used and after this the concentration served as mother liquor. Acetone was used to prepare altered concentrations i.e. 5, 10, 15 and $20 \%$. For the preparation of $5 \%$ concentration of tested plant extracts; $5 \mathrm{ml}$ of the extracted plant material was added in $95 \mathrm{ml}$ concentrated acetone. In the same way 10, 15 and $20 \%$ concentrations were prepared by using acetone.

Repellency bioassay: Filter papers were used to check the repellent actions of the tested plants against $C$. chinensis adults. In repellency bioassay the Area preference method was used to evaluate the potential of repellency. The filter papers were cut into two halves and the diameter of each filter paper was $9 \mathrm{~cm}$. One half of each filter paper was coated with four concentrations of each plant extract whilst the other half of the filter paper was coated with acetone serving as nonexperimental unit (control) for the comparison purposes. Completely Randomized Design (CRD) was used to perform this experiment. Filter paper will be dried for few minutes. Then treated and untreated both the halves of filter papers were clipped together and counted beetles (fifty) were placed in clipped area (center) of each Petri dish. After this number of tested insects on filter paper (on both halves) were calculated after 24 hours intervals.

Progeny inhibition studies: Counted sex pairs (Twenty five) of the test insect were placed in small plastic jars having plant extract treated diet (50 gm grains). Jars having grains treated with only acetone were used for comparison (as a control). Released target insects were discarded from the rearing jars after 7 days and insect population buildup findings were computed after the exposure period of 30 and 60 days. Then percent inhibition rates were computed using by Abbott's formula (1925):

$\left(\right.$ Corrected growth inhibition \%) $=\frac{\mathrm{T}-\mathrm{C}}{100-\mathrm{C}} \times 100$

Here, $\mathrm{C}=$ presents the progeny in control units; $\mathrm{T}=$ denotes the numbers (progeny) in treated jars

Data analysis: The collected data were analyzed Analysis of Variance using Statistical software (Stat Soft 8.0) and the comparison of treatment means was done by using Tukey's HSD test at $\alpha=5$ percent. 
In case of FSD strain of the Callosobruchus chinensis A. indica and M. koenigii caused highest repellence (93.32 and $90.07 \%)$ at $(20 \%)$ dilution after longest time of exposure (48 hrs). In case of $N$. tobacum extract, maximum repellency $(84.76 \%)$ was observed at the peak dilution (20\%) after longest time of exposure (48 hrs). In case of Liquorice, maximum repellency $(78.87 \%$ ) was noticed at $20 \%$ dilution of the extracted plant material used after $48 \mathrm{hrs}$ (longest exposure time) of the post treatment whilst comparatively lowest mean repellency $(48.89 \%)$ was noticed at lowest concentration $(5 \%)$ the treatment after post treatment period of $12 \mathrm{hrs}$ (shortest exposure period of the treatment, applied). In repellency, $95.16 \%$ value against Lahore strain of $C$. chinensis was observed in case of Azadirachta indica followed by N. tobacum $91.06 \%$. M. koenigii produced 87.27 $\%$ repellency of the $C$. chinensis whereas lowest repellency $82.04 \%$ was exhibited by Liquorice.

Table 4 and 5 shows the progeny inhibition $\%$ of Faisalabad and Lahore straThe bioassay (progeny inhibition) revealed that in case of $A$. indica highest mean ins of Callosobruchus chinensis L. caused by various dilutions of Murraya koenigii, Azadirachta indica, Nicotiana tobacum and Liquorice after 30 and 60 days respectively. Results shows that in case of A.indica highest mean inhibition $(78.12 \%)$ were observed at the highest dose rate (20\%) of plant extract used after longest post treatment period (60 days). Relatively lowest inhibition $(34.57 \%)$ was noticed at $5 \%$ after $30 \mathrm{hrs}$ of time period.
Similarly, within the exposure period of 30 and 60 days at 20 percent concentration inhibition values were 60.89 and 78.12 respectively. In case of Liquorice highest mean inhibition $(61.26 \%)$ was observed at the peak dose rate $(20 \%)$ of the treatment (extract) used after longest post treatment period (60 days). While comparatively minimum inhibition (28.21\%) was observed at $5 \%$ after $30 \mathrm{hrs}$ of time period in Liquorice. Similarly, within the 30 and 60 days of the exposure time at 20 percent concentration inhibition values were 50.35 and $61.26 \%$ respectively. In repellency, $95.16 \%$ value against Lahore strain of $C$. chinensis was observed at 20 $\%$ concentration in case of $A$. indica whereas lowest $82.04 \%$ was by Liquorice. In case of progeny inhibition of Lahore strain, highest $85.03 \%$ was recorded at $20 \%$ concentration of the $A$. indica while relatively lowest $67.41 \%$ was recorded at $20 \%$ concentration of the N. tobacum.

\section{DISCUSSION}

Findings of the repellency bioassay revealed that repellency ranged from $60-93 \%$ during the bioassay with the application of $A$. indica extract. Mean repellency was found increased with rise in the extract concentration and exposure period and vice versa. Highest mean repellency $(93.32 \%)$ was observed at $(20 \%)$ peak dilution of the applied treatment (extracted plant material) used after longest time of exposure (48 hrs). However, relatively low repellency $(60.87 \%)$ was examined

Table 1. Repellence (\%) of Faisalabad and Lahore Strains of $C$. chinensis L. caused by various dilutions of Azadirachta indica, Liquorice, Murraya koenigii and Nicotiana tobacum after 12 hours exposure period.

\begin{tabular}{|c|c|c|c|c|c|c|c|c|c|}
\hline \multirow[b]{2}{*}{$\begin{array}{l}\text { Time } \\
\text { (hours) }\end{array}$} & \multirow[b]{2}{*}{$\begin{array}{c}\text { Concentra- } \\
\text { tions }(\%)\end{array}$} & \multicolumn{3}{|c|}{ Faisalabad Strain } & \multicolumn{5}{|c|}{ Lahore Strain } \\
\hline & & A. indica & M. koenigii & N. tobacum & Liquorice & A. Indica & M. koenigii & N. tobacum & Liquorice \\
\hline 12 & 5 & 6 & & & & & & & \\
\hline 12 & 10 & $70.01 \pm 1.92 \mathrm{f}$ & 65.56 & $60.03 \pm 1.92 \mathrm{gh}$ & $2 \mathrm{f}$ & $75 \mathrm{~h}$ & $3 \mathrm{fg}$ & 68.16 & $33 \mathrm{fg}$ \\
\hline 12 & 15 & $75.56 \pm 1.11 \mathrm{de}$ & $73.51 \pm 2.44 \mathrm{e}$ & $62.24 \pm 2.23 \mathrm{gh}$ & $58.86 \pm 1.92 \mathrm{e}$ & $76.31 \pm 1.33 \mathrm{efg}$ & $71.00 \pm 1.33 \mathrm{ef}$ & $74.7 \pm 1.33 \mathrm{gh}$ & $57.67 \pm 1.33 \mathrm{ef}$ \\
\hline 12 & 20 & $85.54 \pm 1.92 \mathrm{~b}$ & $77.79 \pm 1.32 \mathrm{~d}$ & $67.75 \pm 2.54 \mathrm{ef}$ & $63.31 \pm 1.11 \mathrm{~d}$ & $82.17 \pm 1.87 \mathrm{def}$ & $74.24 \pm 1.33 \mathrm{bc}$ & $76.02 \pm 1.53 \mathrm{ef}$ & $68.27 \pm 1.33 \mathrm{~b}$ \\
\hline
\end{tabular}

Table 2. Repellence (\%) of Faisalabad and Lahore Strains of $C$. chinensis L. caused by various dilutions of Azadirachta indica, Liquorice, Murraya koenigii and Nicotiana tobacum after 24 hours exposure period.

\begin{tabular}{|c|c|c|c|c|c|c|c|c|c|}
\hline \multirow[b]{2}{*}{$\begin{array}{l}\text { Time } \\
\text { (hours) }\end{array}$} & \multirow[b]{2}{*}{$\begin{array}{l}\text { Concentra- } \\
\text { tion }(\%)\end{array}$} & \multicolumn{4}{|c|}{ Faisalabad Strain } & \multicolumn{4}{|c|}{ Lahore Strain } \\
\hline & & A. indica & M. koenigii & N. tobacum & Liquorice & A. indica & M. koenigii & N. tobacum & Liquorice \\
\hline 24 & 5 & $74.43 \pm 1.11 \mathrm{def}$ & $68.89 \pm 1.11 \mathrm{fg}$ & $65.53 \pm 2.87 \mathrm{~g}$ & $54.43 \pm 1.11 \mathrm{f}$ & $76.60 \pm 1.28 \mathrm{efg}$ & $67.33 \pm 1.33 \mathrm{ef}$ & $69.29 \pm 1.43 \mathrm{fgh}$ & $58.26 \pm 1.18 \mathrm{ef}$ \\
\hline 24 & 10 & $76.67 \pm 1.92 \mathrm{de}$ & $70.02 \pm 1.92 \mathrm{f}$ & $69.54 \pm 1.92 \mathrm{ef}$ & $63.32 \pm 1.92 \mathrm{~d}$ & $83.67 \pm 1.33 \mathrm{cde}$ & $71.16 \pm 1.63 \mathrm{de}$ & $74.41 \pm 2.62 \mathrm{efg}$ & $61.20 \pm 1.33 \mathrm{de}$ \\
\hline 24 & 15 & $82.23 \pm 1.11 \mathrm{~cd}$ & $74.42 \pm 1.11 \mathrm{e}$ & $71.12 \pm 1.11 \mathrm{e}$ & $67.76 \pm 1.34 \mathrm{~cd}$ & $87.64 \pm 1.33 \mathrm{~cd}$ & $73.00 \pm 1.33 \mathrm{~cd}$ & $77.04 \pm 1.33 \mathrm{de}$ & $64.14 \pm 1.33 \mathrm{~cd}$ \\
\hline 24 & 20 & $86.56 \pm 1.24 b c$ & $84.45 \pm 1.92 \mathrm{c}$ & $76.67 \pm 1.11 \mathrm{~d}$ & $68.87 \pm 2.56 \mathrm{~cd}$ & $91.07 \pm 1.13 \mathrm{ab}$ & $80.10 \pm 2.27 \mathrm{ab}$ & $83.37 \pm 2.87 \mathrm{~cd}$ & $69.30 \pm 1.87 \mathrm{~b}$ \\
\hline
\end{tabular}

Table 3. Repellence (\%) of Faisalabad and Lahore Strains of $C$. chinensis L. caused by various dilutions of Azadirachta indica, Liquorice, Murraya koenigii and Nicotiana tobacum after 48 hours exposure period.

\begin{tabular}{|c|c|c|c|c|c|c|c|c|c|}
\hline \multirow[b]{2}{*}{$\begin{array}{l}\text { Time } \\
\text { (hours) }\end{array}$} & \multirow[b]{2}{*}{$\begin{array}{l}\text { Concentra } \\
\text {-tions }(\%)\end{array}$} & \multicolumn{4}{|c|}{ Faisalabad Strain } & \multicolumn{4}{|c|}{ Lahore Strain } \\
\hline & & A. indica & M. koenigii & N. tobacum & Liquorice & A. Indica & M. koenigii & N. tobacum & Liquorice \\
\hline 48 & 5 & $80.02 \pm 1.52 \mathrm{cde}$ & $78.89 \pm 1.57 \mathrm{~d}$ & $77.78 \pm 1.11 \mathrm{~d}$ & $58.88 \pm 1.12 \mathrm{e}$ & $84.00 \pm 1.33 \mathrm{cde}$ & $76.03 \pm 2.08 \mathrm{~cd}$ & $84.17 \pm 1.58 \mathrm{~cd}$ & $63.14 \pm 1.23 \mathrm{~cd}$ \\
\hline 48 & 10 & $84.43 \pm 1.11 \mathrm{~cd}$ & $82.23 \pm 1.11 \mathrm{c}$ & $81.12 \pm 2.93 b c$ & $70.03 \pm 2.11 \mathrm{c}$ & $86.04 \pm 1.33 \mathrm{~cd}$ & $78.43 \pm 1.83 \mathrm{ab}$ & $89.32 \pm 1.33 b c$ & $65.21 \pm 1.13 b c$ \\
\hline 48 & 15 & $88.87 \pm 1.11 b$ & $87.76 \pm 1.27 \mathrm{ab}$ & $83.32 \pm 1.92 \mathrm{ab}$ & $75.56 \pm 1.92 \mathrm{ab}$ & $92.19 \pm 1.43 \mathrm{ab}$ & $82.18 \pm 1.33 \mathrm{ab}$ & $90.89 \pm 2.16 \mathrm{ab}$ & $70.08 \pm 1.33 b$ \\
\hline 48 & 20 & $93.32 \pm 1.92 \mathrm{a}$ & $90.07 \pm 1.11 \mathrm{a}$ & $84.76 \pm 1.92 \mathrm{a}$ & $78.87 \pm 1.11 \mathrm{a}$ & $95.16 \pm 1.54 \mathrm{a}$ & $87.27 \pm 2.33 \mathrm{a}$ & $91.06 \pm 1.53 \mathrm{a}$ & $82.04 \pm 2.03 \mathrm{a}$ \\
\hline
\end{tabular}


Haidri, Ahmad, Hasan \& Javed

Table 4. Progeny inhibition \% of Faisalabad and Lahore Strains of $C$. chinensis L. caused by various dilutions of Murraya koenigii, Azadirachta indica, Liquorice and Nicotiana tobacum after 30 days post treatment development.

\begin{tabular}{|c|c|c|c|c|c|c|c|c|c|}
\hline \multirow[b]{2}{*}{ Days } & \multirow[b]{2}{*}{$\begin{array}{l}\text { Conentra- } \\
\text { tions (\%) }\end{array}$} & \multicolumn{4}{|c|}{ Faisalabad Strain } & \multicolumn{4}{|c|}{ Lahore Strain } \\
\hline & & A. Indica & M. koenigii & N. tobacum & Liquorice & A. Indica & M. oenigii & N. tobacum & Liquorice \\
\hline 30 & 5 & 34.5 & 1 & & & $77 \mathrm{f}$ & $41.28=$ & & 36. \\
\hline 30 & 10 & $51.26 \pm 1.11 \mathrm{~d}$ & $42.10 \pm 1.92 \mathrm{e}$ & $40.36=$ & $37.03=$ & $53.21 \pm 0.67 \mathrm{e}$ & $46.15 \pm 0.77 \mathrm{e}$ & $\pm 0.91 \mathrm{f}$ & 39.12 \\
\hline 30 & 15 & $54.46 \pm 1.92 \mathrm{e}$ & $49.62 \pm 2.44 d$ & $46.36 \pm 1.92 \mathrm{~d}$ & $44.14 \pm 2.23 \mathrm{e}$ & $64.35 \pm 0.76 \mathrm{~d}$ & $59.05 \pm 0.47 \mathrm{c}$ & $43.78 \pm 0.87 \mathrm{~d}$ & $48.08 \pm 0.77 \mathrm{e}$ \\
\hline 30 & 20 & $60.89 \pm 1.92 \mathrm{c}$ & $58.39 \pm 1.32 \mathrm{c}$ & $55.21 \pm 2.54 \mathrm{~b}$ & $50.35 \pm 1.11 \mathrm{c}$ & $72.17 \pm 2.13 b$ & $64.49 \pm 0.87 \mathrm{~b}$ & $54.13 \pm 0.94 \mathrm{c}$ & $60.42 \pm 1.07 \mathrm{c}$ \\
\hline
\end{tabular}

Table 5. Progeny inhibition \% of Faisalabad and Lahore Strains of $C$. chinensis $L$. caused by various dilutions of Murraya koenigii, Azadirachta indica, Liquorice and Nicotiana tobacum after 60 days post treatment development.

\begin{tabular}{|c|c|c|c|c|c|c|c|c|c|}
\hline \multicolumn{3}{|c|}{ Faisalabad Strain } & \multicolumn{7}{|c|}{ Lahore Strain } \\
\hline Days & $\begin{array}{c}\text { Concentra- } \\
\text { tions }(\%)\end{array}$ & A. Indica & M. koenigii & N. tobacum & Liquorice & A. Indica & M. koenigii & N. tobacum & Liquorice \\
\hline 60 & 5 & $56.17 \pm 1.57 d$ & $51.08 \pm 1.52 \mathrm{~d}$ & $47.28 \pm 1.11 \mathrm{~d}$ & $41.48 \pm 1.12 \mathrm{e}$ & $65.14 \pm 0.27 d$ & $55.04 \pm 0.47 \mathrm{~d}$ & $40.26 \pm 0.37 \mathrm{e}$ & $45.19 \pm 0.55 \mathrm{~d}$ \\
\hline 60 & 10 & $62.79 \pm 1.11 \mathrm{c}$ & $58.43 \pm 1.11 \mathrm{c}$ & $52.12 \pm 1.92 \mathrm{c}$ & $48.13 \pm 2.11 d$ & $68.01 \pm 0.31 \mathrm{c}$ & $63.77 \pm 0.37 c$ & $46.13 \pm 0.47 \mathrm{~d}$ & $61.01 \pm 0.55 \mathrm{c}$ \\
\hline 60 & 15 & $72.51 \pm 1.11 b$ & $67.16 \pm 1.27 b$ & $64.32 \pm 2.93 \mathrm{a}$ & $58.87 \pm 1.11 \mathrm{~b}$ & $74.54 \pm 0.98 b$ & $69.24 \pm 1.07 \mathrm{~b}$ & $58.02 \pm 1.03 b$ & $64.30 \pm 0.34 b$ \\
\hline 60 & 20 & $78.12 \pm 1.92 \mathrm{a}$ & $71.17 \pm 1.11 \mathrm{a}$ & $66.56 \pm 1.92 \mathrm{a}$ & $61.26 \pm 1.92 \mathrm{a}$ & $85.03 \pm 0.97 \mathrm{a}$ & $78.31 \pm 1.37 \mathrm{a}$ & $67.41 \pm 1.37 \mathrm{a}$ & $71.26 \pm 1.45 \mathrm{a}$ \\
\hline
\end{tabular}

at lowest concentration $5 \%$ after $12 \mathrm{hrs}$ of the treatment (extract), applied. Repellency ranged from 55-90\% during the bioassay with extract of M. koenigii. Results showed that maximum repellency $(90.07 \%)$ was observed at $20 \%$ dilution of the extracted plant material (M. koenigii) used after longest time of exposure $(48 \mathrm{hrs})$. While relatively low value $(55.53 \%)$ of repellency was noticed at lowest concentration $(5 \%)$ of the extract. Maximum repellency $(84.76 \%)$ was noted after the longest exposure time ( $48 \mathrm{hrs})$ at the peak dilution (20\%) of the extracted plant material ( $N$. tobacum). Comparatively lowest repellency (52.21\%) was noted after 12 hrs of exposure period at 5\%. In case of Liquorice, maximum repellency $(78.87 \%$ ) was noticed at $20 \%$ dilution of extracted plant material used after $48 \mathrm{hrs}$ (longest exposure time) of the post treatment. Comparatively lowest repellency (48.89\%) was noted after the time of exposure of $12 \mathrm{hrs}$ at $5 \%$ of the concentration of the extract. Our repellency findings are also close to Muntaha et al., 2017 who used extract of A. indica and recorded up to $90 \%$. Findings of our study are close with Rehman et al. (2018). Results are in accordance with Sharma et al. (2003) who evaluated repellency results.

Studies on post treatment progeny inhibitory effect of the plant extracts revealed that in case of $A$. indica highest mean inhibition (78.12\%) was observed at the peak dose rate (20\%) of the treatment (extract) used after longest post treatment period (60 days). Relatively lowest inhibition (34.57\%) was noticed at $5 \%$ after $30 \mathrm{hrs}$ of time period. Similarly, within the exposure time of 30 and 60 days at 20 percent concentration inhibition values were 60.89 and 78.12 respectively. In case of Liquorice highest mean inhibition (61.26\%) was observed at the peak dose rate $(20 \%)$ of the treatment (extract) used after longest post treatment period (60 days). While comparatively minimum inhibition $(28.21 \%)$ was observed at 5\% after 30 hrs of time period in Liquorice. Similarly, at 20 percent concentration inhibition values were 50.35 and 61.26 $\%$ within the exposure time of 30 and 60 days, respectively. Our findings are close to Sultana et al. (2012) who evaluated the growth inhibition effects of three edible oils against Callosobruchus chinensis. Results of our study are also close to Sagheer et al. (2011) who evaluated the inhibitory effects of some plant extracts against Tribolium castaneum. Slight difference may be due to difference in two insect species. In repellency, $95.16 \%$ value against Lahore strain of $C$. chinensis was observed at $20 \%$ concentration in case of $A$. indica whereas lowest $82.04 \%$ was by Liquorice. In case of progeny inhibition of Lahore strain, highest $85.03 \%$ was recorded at $20 \%$ concentration of the A. indica while relatively lowest $67.41 \%$ was recorded at $20 \%$ concentration of the N. tobacum. Our outcomes progeny inhibitions are close to Muntaha et al., 2017 who used A. indica against $C$. chinensis.

Conclusion: Keeping in view the results of current work, it is concluded that all the concentrations of plant extracts have repellent effects against $C$. chinensis. A. indica and exhibited highest mean repellency at high concentration (20\%) of the applied treatment used after (48 hrs) in both strains. $N$. tobacum, M. koenigii also showed highest repellency whereas lowest repellency was exhibited by Liquorice. Therefore, plant-based materials can be useful for the eco-friendly controlling of the stored insect pests.

\section{REFRENCES}

Abbott, W.S. 1925. A method of computing the effectiveness of an insecticide. J. Econ. Entomol. 18:265-267. 
Anand, P., J. Rao and V. Nandagopal. 2008. Future of botanical pesticides in rice, wheat, pulses and vegetables pest management. J. Biopesticides 1:154-169.

Araya, G. S. and G. Emana. 2009. Evaluation of botanical plant powders against Zabrotes subfasciatus (Boheman) (Coleoptera: Bruchidae) in stored haricot beans under laboratory Condition. African J. Agri. Res. 4:1073-1079.

Aslam, M., F. A. Shaheen, M. A. Abbas and A. Saba. 2004. Management of Callosobruchus chinensis Linnaeus through use of resistance in stored chickpea varieties. J. Agric. Sci. 2:82-84.

Boeke, S. J., I. R. Baumgart, J. J. A van-Loon, A. van-Huis, M. Dicke and D. K. Kossou. 2004. Toxicity and repellence of African plants traditionally used for the protection of stored cowpea against Callosobruchus maculatus. J. Stored Prod. Res.40:423-438.

Chinnaiah, C., S. Kuttalam and A. Regupathy. 1998. Harvest time residue of lindane and chlorpyriphos in paddy. Pestic. Res. J. 10:91-94.

Das, A, P. and K. B. Sarmah. 2005. Callosobruchus chinensis L. (Bruchids) cause damage to number of important pulse grain's during storage. Legum. Res. An Int. J. 28:74-76.

Debashri, M. and M. Tamal. 2012. A Review on efficacy of Azadirachta indica A. Juss based biopesticides: An Indian perspective. Res. J. Recent Sci. 1:94-99.

Environmental Protection Agency (EPA). 2001. Protection of stratospheric ozone: process for exempting quarantine and preshipment applications of methyl bromide. United States Environmental Protection Agency, Federal Register. 66:37752-37769.

Gujar, G. T and T. D. Yadav. 1978. Feeding of Callosobruchus maculatus (Fab.) and Callosobruchus chinensis L. in green gram. Ind. J. Entomol. 40:108-112.

Guleria, S. and A. K. Tiku. 2009. Botanicals in Pest Management: Current Status and Future Perspectives, In: Rajinder, P. and Ashok, K. D. (Eds.), Integrated Pest Management: Innovation-Development Process. Springer Netherlands.pp. 317-329.

Isman, M. B. 2002. Plant essential oils for pest and disease management. J. Crop Prot. 19: 603-608.

Maheshwari, H. K. and S. C. Dwivedi. 1996. Evaluation of botanicals for the management of Tribolium castaneum (Coleoptera: Tenebrionideae). J. Insect Environ. 2:72-73.

Muntaha, S., M. Sagheer, M. Hasan and S. T. Sahi. 2017. Repellent and Growth Inhibitory Impact of Plant Extracts and Synthetic Pyrethroids on Three Strains of Callosobruchus chinensis (L.). Pak. J. Zool. 49:581-589.
Naveena, N. L., C. S. Jagadeesh Babu, K. Prashanth and Chandrashekaraiah. 2009. Screening of field bean (Lablab purpures L.) Genotypes against Bruchid (Callosobruchus theobromae L.). International J.Biol. Sci. 1:121-125.

Reddy, A.V., R.D. Sunitha and D.V.R. Vishnu. 2012. Evaluation of botanical and other extracts against plant hoppers in rice. J. Bio. Pest. 5:57-61.

Rehman, H., S. Mirza, M. Hasan, Q. Ali, H.A. Shakir and M. Yasir. 2018. Repellent potential of three medicinal plant extracts against Tribolium castaneum (Coleoptera: Tenebrionidae). Punjab Univ. J. Zool. 33:121-126.

Righi-Assia, A.F. M.A. Khelil, F. Medjdoub-Bensaad and K. Righi. 2010. Efficacy of oils and powders of some medicinal plants in biological control of the pea weevil (Callosobruchus chinensis L.). J. Afr. Agri. Res.5:14741481.

Sagheer, M., M. Hasan, M.A. Latif and J. Iqbal. 2011. Evaluation of some indigenous medicinal plants as a source of toxicant, repellent and growth inhibitors against Tribolium castaneum (Coleoptera:Tenebrionidae). Pak. Entomol. 33:87-91.

Sharma, R., R. Devi, R.K. Sharma and J.C. Mehla. 2013. Efficacy of some botanicals against pulse beetle, Callosobruchus chinensis (L.) in Chickpea. Legum. Res. An Int. J. 36:125-130.

Sharma, S. S., G. S. Yadav and B. S. Chillar. 2003. Repellent activity of some plant extracts against Callosobruchus chinensis (L.) in chickpea grains. Annals of Biology. 19: 217-218.

Srivastava, C. and D. Singh. 2002. Study of phosphine resistance in Rhyzopertha dominica and Callosobruchus maculates. Indian J. Entomol. 64:377-378.

Subramanyam, B. and D.W. Hagstrum. 1995. Resistance measurement and management In Integrated Management of Insects in Stored Products (B. Subramanyam and D.W. Hagstrum, eds.). Marcel Dekker, New York. pp. 331-397.

Sultana, A., M. M. Ahasan and S. Begum. 2012. Effects of three edible oils on oviposition preference, adult emergence and longevity of Callosobruchus chinensis on phaseolus aureus seeds. J. Expt. Biosci. 3:45-49.

Verma, S. C. and P. Anandhi. 2010. Biology of pulse beetle (Callosobruchus chinensis Linn. (Coleoptera: Bruchidae) and their management through botanicals on stored mung grains in Allahabad region. Legum. Res. An Int. J. 33:38-39. 